\title{
HOST RESPONSES OF WHEAT GENOTYPES TO PRATYLENCHUS BRACHYURUS AND MELOIDOGYNE JAVANICA
}

\author{
Diego Francisco Gonçalves; Ana Paula Mendes Lopes²*; Heriksen Higashi Puerari²; Claúdia Regina Dias-Arieira ${ }^{1}$ \\ ${ }^{1}$ Engenheiro Agrônomo; Universidade Estadual de Maringá - Campus Regional de Umuarama; d.francisco-g@hotmail.com \\ ${ }^{2}$ Mestranda em Proteção de Plantas, Universidade Estadual de Maringá;*anna_apml@hotmail.com \\ *Autor para correspondência \\ ${ }_{2}^{2}$ Doutorando em Proteção de Plantas, Universidade Estadual de Maringá; heriksenhp@hotmail.com \\ ${ }^{1}$ Professora associada; Universidade Estadual de Maringá - Campus Regional de Umuarama; crdiasarieira@hotmail.com
}

Artigo enviado em 24/03/2017, aceito em 21/03/2018 e publicado em 10/04/2018

\begin{abstract}
This work aimed to evaluate the host response of twelve wheat genotypes to Pratylenchus brachyurus and Meloidogyne javanica in two distinct periods. Tests were carried out in greenhouse with an initial population of 1,200 nematodes per pot, each containing $700 \mathrm{~mL}$ substrate and seven wheat seedlings. Evaluation was done at 60 and 83 days after inoculation in the first and the second experiment, respectively. At 60 days after inoculation with $P$. bracbyurus, all cultivars were resistant to the nematode, presenting reproduction factor $\mathrm{RF}<1$. At 83 days after inoculation, only the cultivars $\mathrm{F}$. Cristalina and IPR 85 showed $\mathrm{RF}<1$, the others were susceptible to the $P$. brachyurus. At 60 days after M. javanica inoculation, BRS Sabiá, F. Cristalina, IPR 144, IPR Catuara Tm, Quartzo and FPS Nitron presented RF $>1$. At 83 days, cv. Gralha Azul, in addition to those already mentioned, presented RF $>1$. The cultivars BRS Gaivota and IPR 85 were susceptible to M. javanica in both experiments. It was concluded that the twelve wheat genotypes presented different host responses to the studied nematodes and most of them were susceptible.
\end{abstract}

Keywords: root-lesion nematode; root-knot nematode; genetic resistance; Triticum.

Resumo - Este trabalho teve como objetivo avaliar a reação de doze genótipos de trigo a Pratylencbus brachyurus e Meloidogyne javanica, em dois períodos distintos. Os testes foram conduzidos em casa de vegetação, sob população inicial de 1200 nematoides por vaso contendo $700 \mathrm{ml}$ de substrato e sete plântulas de trigo. As avaliações foram realizadas aos 60 e 83 dias após inoculação no primeiro e segundo experimento, respectivamente. Para P. brachyurus aos 60 dias todas as cultivares apresentaram fator de reprodução $(\mathrm{FR})<1$. Aos 83 dias, apenas as cultivares F. Cristalina e IPR 85 apresentaram FR $<1$, sendo as demais suscetíveis a P. brachyurus. 60 dias após a inoculação de $M$. javanica, BRS Sabiá, F. Cristalina, IPR 144, IPR Catuara Tm, Quartzo e FPS Nitron apresentaram RF> 1. Aos 83 dias, cv. A Gralha Azul, além dos já mencionados, apresentou RF> 1. As cultivares BRS Gaivota e IPR 85 foram suscetíveis a $M$. javanica em ambos os experimentos. Concluiu-se que os doze genótipos de trigo apresentaram diferentes respostas de hospedeiro aos nematoides estudados sendo a maioria susceptível.

Palavras-chave: nematoide das lesões radiculares; nematoide das galhas; resistência genética; Triticum.

\section{INTRODUCTION}

Wheat (Triticum aestivum L.) is one of the most consumed crops in the world. Although wheat farming is an ancient practice, wheat areas have expanded in Brazil from the 40's, mainly in the southern. In Brazil, the produced wheat grains account for 6.23 million tons harvested in area of 2.7 million hectares (CONAB, 2015). Further expansion of the cultivated area is even expected mainly because the wheat cultivation in new areas of the Cerrado region.

Wheat is a winter crop commonly cultivated in succession to soybean, which is susceptible to different nematode species. About 100 nematode species are related to soybean cultivation worldwide. In Brazil, the most important are the root-lesion nematode (Pratylenchus brachyurus (Godfrey) Filipjev and Sch. Stekhoven), the root-knot nematode (Meloidogyne spp.), the soybean cyst nematode (Heterodera glycines Ichinohe), and the reniform nematode (Rotylenchulus reniformis Linford and Oliveira) (DIAS et al., 2010). Various species of nematodes are also related to the Brazilian wheat crops, which includes the root-knot nematode and the root-lesion nematode (Pratylenchus spp.), the cereal cyst nematode (Heterodera avenae Wollenweber) and the wheat gall nematode (Anguina tritici Steinbuch), being the last two quarantine pests in Brazil. 
The susceptibility or reduction in wheat yield related to root-lesion nematode was reported in American researches (SMILEY et al., 2005), as well as observed smaller wheat plants parasitized by the rootknot nematode (NYCZEPIR et al., 1984).

Nematodes are difficult to control because the most management techniques have limitations when applied singly. Crop rotation is usually recommended practice for the control of nematodes, but the number of botanic species that can be used is reduced due the wide host range of some nematodes genera, such as root-knot and root-lesion nematodes.

Some researchers have been progressed in identifying and mapping genes of resistance to rootlesion nematodes. However, these studies focus only on species from temperate countries, such as $P$. thornei Sher and Allen and $P$. neglectus Rensch (WILLIAMS et al., 2002; LINSELL et al., 2014; SMILEY et al., 2014). Research about wheat susceptibility to Meloidogyne spp. is scarce. Little information is found in Brazil, especially from the last two decades.

The knowledge of wheat susceptibility to the soybean nematodes is essential, since cultivation in succession favors an increased nematode population in soybean-wheat areas. Due to the lack of information about the subject, the present study aimed to evaluate the susceptibility of twelve wheat genotypes to Meloidogyne javanica (Treub) Chitwood and P. brachyurus.

\section{MATERIAL AND METHODS}

Experiments occurred in greenhouse at coordinates $23^{\circ} 47^{\prime} 28.46 " \mathrm{~S}$ and $53^{\circ} 15^{\prime} 23.46$ " W, 430 $\mathrm{m}$ above sea level. For tests in pots, twelve wheat genotypes and one control were grown under greenhouse conditions. Completely randomized design was used for statistical analyses with six replicates for each treatment, in two experimental periods. The first experiment with $P$. brachyurus occurred between September and November 2015 and was evaluated at 60 days after inoculation (DAI). The second experiment was done between February and May 2016 and evaluated at 83 DAI. The minimum and maximum average temperatures during these two experimental periods were 19.77 and $29.30{ }^{\circ} \mathrm{C}$ and 21.13 and 30.00 ${ }^{\circ} \mathrm{C}$, respectively. The experiments with $M$. javanica occurred between January and March 2016 and between May and August 2016 and were evaluated at $60 \mathrm{DAI}$ and $83 \mathrm{DAI}$, respectively. The minimum and maximum average temperatures during these two experimental periods were 21.47 and $31.00{ }^{\circ} \mathrm{C}$ and 14.32 and $24.10^{\circ} \mathrm{C}$, respectively.
The experimental plots contained $700 \mathrm{~mL}$ of a mixture of soil and sand (2:1), previously autoclaved at $120{ }^{\circ} \mathrm{C}$ for two hours. Soil was constituted by $84.20 \%$ sand, $1.15 \%$ clay and $14.65 \%$ silt. Based on chemical analysis, soil acidity was corrected with $0.4 \mathrm{~g}$ of limestone (PRNT=85\%) and fertility with $0.24 \mathrm{~g}$ of NPK 02:06:06 and 0.01 $\mathrm{g}$ of $\mathrm{KCl}$ per plot.

Then, 10 wheat seeds were sown into each experimental plot and the treatments were characterized by the following cultivars: IPR Catuara TM, IPR 144, IPR 85, BRS Gralha Azul, BRS Sabiá, BRS Gaivota, BRS Tangará, Marfim, FPS Nitron, T.Bio Iguaçu, Quartzo and F. Cristalina. For the viability (control) of the $P$. brachyurus and $M$. javanica inoculum, soybean cv. Syngenta 1363 RR and tomato cv. Santa Clara were used, respectively.

At 10 days after germination, thinning was performed for keeping only seven wheat seedlings (treatments), one soybean or tomato plant (controls) per experimental plot. On the same day, plants were inoculated with 1,200 specimens of $P$. brachyurus or 1,200 eggs and second stage juveniles (J2) of $M$. javanica, by pipetting of $2 \mathrm{~mL}$ aliquots of nematode suspension into two $3 \mathrm{~cm}$-deep holes in either side of the seedling. After inoculation, the holes were covered with soil. The both inoculum were obtained from pure populations of nematodes kept in soybeans under greenhouse conditions. $P$. brachyurus and $M$. javanica were extracted from soybean roots according to methodology proposed by Coolen and D'Herde (1972) and Boneti and Ferraz (1981), respectively. The nematode extracts were quantified in Peters slide under optical microscope.

At the end of the experimental periods, plants were collected and aerial parts removed. Roots were carefully washed and dried on absorbent paper. The root fresh weight was obtained prior to nematode extraction. The samples were evaluated for total number of nematodes per roots, obtained in Peters slide under optical microscope. The total number of nematodes was divided by the root weight to determine the nematodes number per gram of root. In addition, the total number of nematodes was used to calculate the reproduction factor (RF), according to methodology proposed by Oostenbrink (1966), RF = $\mathrm{FP} / \mathrm{IP} ; \mathrm{FP}=$ final population; IP = initial population. Thereby, plants with RF> 1.0 are susceptible, with $\mathrm{RF}$ $\leq 1.0$ are resistant, and with $\mathrm{RF}=0.0$ are immune.

Data were submitted to variance analysis and means compared by Scott-Knott test at 5\% probability. Original values were transformed by $\sqrt{ }(x+0.5)$ using the computer statistical analysis system Sisvar (Ferreira 2008). 


\section{RESULTS}

At 60 DAI, the wheat genotypes inoculated with $P$. brachyurus presented $\mathrm{RF}<1.0$ (Table 1) and total number of nematodes lower than the control. No statistical difference was observed among them (Table 1). However, the number of nematodes per gram of root revealed two distinct groups: the first, less susceptible with 11-88 nematodes/g of root and the second, more susceptible with more than 144 nematodes/g of root. Both groups presented values lower than soybean (211 nematodes/g of root).
At 83 DAI, the total number of $P$. brachyurus in BRS Gaivota, Quartzo, BRS Gralha Azul, FPS Nitron and Marfim were statistically equal to the control (Table 1). The number of nematodes per gram of root of BRS Sabiá and FPS Nitron cultivars was statistically equal to the control, with averages higher than the other treatments. Only F. Cristalina and IPR 85 cultivars presented $\mathrm{RF}<1.0$ at $83 \mathrm{DAI}$, the others were considered susceptible. Cultivars BRS Gaivota, Quartzo, BRS Gralha Azul, FPS Nitron and Marfim presented RF statistically equal to the control. Cultivars IPR 144, IPR Catuara TM, BRS Tangará, BRS Sabiá, T. Bio Iguaçu presented RF ranging from 1.22 and 1.85 (Table 1).

Table 1: Total nematode, nematode/g of root and Reproduction Factor (RF) of Pratylenchus brachyurus in different wheat cultivars inoculated with 1,200 nematode specimens at two different experimental periods.

\begin{tabular}{lccc}
\hline & Year 2015 (evaluated at 60 days after inoculation) & \\
\hline Treatment & Total Nematode & Nematode/g of root & RF \\
\hline Soybean & $2023 \mathrm{a}$ & $211 \mathrm{a}$ & $1.69 \mathrm{a}$ \\
F. Cristalina & $553 \mathrm{~b}$ & $80 \mathrm{c}$ & $0.46 \mathrm{~b}$ \\
IPR 85 & $870 \mathrm{~b}$ & $144 \mathrm{~b}$ & $0.72 \mathrm{~b}$ \\
IPR 144 & $557 \mathrm{~b}$ & $88 \mathrm{c}$ & $0.46 \mathrm{~b}$ \\
IPR Catuara Tm & $463 \mathrm{~b}$ & $86 \mathrm{c}$ & $0.39 \mathrm{~b}$ \\
BRS Tangará & $425 \mathrm{~b}$ & $62 \mathrm{c}$ & $0.35 \mathrm{~b}$ \\
BRS Gaivota & $128 \mathrm{~b}$ & $11 \mathrm{c}$ & $0.11 \mathrm{~b}$ \\
Quartzo & $275 \mathrm{~b}$ & $35 \mathrm{c}$ & $0.23 \mathrm{~b}$ \\
BRS Sabiá & $283 \mathrm{~b}$ & $49 \mathrm{c}$ & $0.24 \mathrm{~b}$ \\
BRS Gralha Azul & $378 \mathrm{~b}$ & $41 \mathrm{c}$ & $0.31 \mathrm{~b}$ \\
T. Bio Iguaçu & $510 \mathrm{~b}$ & $88 \mathrm{c}$ & $0.42 \mathrm{~b}$ \\
FPS Nitron & $375 \mathrm{~b}$ & $56 \mathrm{c}$ & $0.31 \mathrm{~b}$ \\
Marfim & $745 \mathrm{~b}$ & $75 \mathrm{c}$ & $0.62 \mathrm{~b}$ \\
\hline CV(\%) & 28.2 & 27.9 & 26.7 \\
\hline & $2016(\mathrm{evaluated} \mathrm{at} 83$ days & after inoculation $)$ & \\
\hline Soybean & $5002 \mathrm{a}$ & $1461 \mathrm{a}$ & $4.17 \mathrm{a}$ \\
F. Cristalina & $640 \mathrm{~b}$ & $239 \mathrm{~b}$ & $0.53 \mathrm{~b}$ \\
IPR 85 & $860 \mathrm{~b}$ & $553 \mathrm{~b}$ & $0.72 \mathrm{~b}$ \\
IPR 144 & $1992 \mathrm{~b}$ & $561 \mathrm{~b}$ & $1.66 \mathrm{~b}$ \\
IPR Catuara Tm & $1462 \mathrm{~b}$ & $607 \mathrm{~b}$ & $1.22 \mathrm{~b}$ \\
BRS Tangará & $1939 \mathrm{~b}$ & $390 \mathrm{~b}$ & $1.62 \mathrm{~b}$ \\
BRS Gaivota & $3462 \mathrm{a}$ & $352 \mathrm{~b}$ & $2.89 \mathrm{a}$ \\
Quartzo & $3138 \mathrm{a}$ & $630 \mathrm{~b}$ & $2.62 \mathrm{a}$ \\
BRS Sabiá & $2220 \mathrm{~b}$ & $884 \mathrm{a}$ & $1.85 \mathrm{~b}$ \\
BRS Gralha Azul & $4522 \mathrm{a}$ & $538 \mathrm{~b}$ & $3.77 \mathrm{a}$ \\
T. Bio Iguaçu & $2190 \mathrm{~b}$ & $720 \mathrm{~b}$ & $1.82 \mathrm{~b}$ \\
FPS Nitron & $3580 \mathrm{a}$ & $1076 \mathrm{a}$ & $2.98 \mathrm{a}$ \\
Marfim & $3648 \mathrm{a}$ & $603 \mathrm{~b}$ & 23.6 \\
\hline CV(\%) & 25.9 & 29.8 & $\mathrm{a}$ \\
\hline
\end{tabular}

Means followed by the same letters within a column do not differ statistically according to Scott-Knott test at $5 \%$. Original means were transformed by $\sqrt{ }(\mathrm{x}+0.5)$ for statistical analysis. $\mathrm{CV}=$ coefficient of variation $(\%)$.

In the first experiment with $M$. javanica, the total nematodes and the number of nematodes per gram of root did not differ statistically among BRS
Gaivota, BRS Sabiá and control. Cultivars F. Cristalina, IPR85, IPR 144, IPR Catuara Tm, Quartzo and FPS 
Nitron also presented $\mathrm{RF}>1.0$, therefore were considered susceptible (Table 2).

In the second experiment, cultivars BRS Gaivota and IPR 85 did not differ from the control for the total number of nematodes and RF. However, all cultivars presented the number of nematodes per gram of root lower than the control (Table 2). The lowest value for RF was verified on the cultivar FPS Nitron.

Table 2: Total nematode, nematode/g of root and Reproduction Factor (RF) of Meloidogyne javanica in different wheat cultivars inoculated with 1,200 eggs and J2 at two different experimental periods.

\begin{tabular}{|c|c|c|c|}
\hline \multicolumn{4}{|c|}{ Year 2016 (evaluated at 60 days after inoculation) } \\
\hline Treatment & Total Nematode & Nematode/g of root & $\mathrm{RF}$ \\
\hline Tomato & $2445 \mathrm{a}$ & $856 \mathrm{a}$ & $2.04 \mathrm{a}$ \\
\hline F. Cristalina & $1450 \mathrm{~b}$ & $379 \mathrm{~b}$ & $1.21 \mathrm{~b}$ \\
\hline IPR 85 & $1437 \mathrm{~b}$ & $423 \mathrm{~b}$ & $1.20 \mathrm{~b}$ \\
\hline IPR 144 & $1735 \mathrm{~b}$ & $345 \mathrm{~b}$ & $1.45 \mathrm{~b}$ \\
\hline IPR CatuaraTm & $1345 \mathrm{~b}$ & $384 \mathrm{~b}$ & $1.12 \mathrm{~b}$ \\
\hline BRS Tangará & $1120 \mathrm{~b}$ & $316 \mathrm{~b}$ & $0.93 \mathrm{~b}$ \\
\hline BRS Gaivota & $2785 \mathrm{a}$ & $321 \mathrm{~b}$ & $2.32 \mathrm{a}$ \\
\hline Quartzo & $1517 \mathrm{~b}$ & $337 \mathrm{~b}$ & $1.26 \mathrm{~b}$ \\
\hline BRS Sabiá & $2702 \mathrm{a}$ & $747 \mathrm{a}$ & $2.25 \mathrm{a}$ \\
\hline BRS Gralha Azul & $837 \mathrm{~b}$ & $132 \mathrm{~b}$ & $0.70 \mathrm{~b}$ \\
\hline T. Bio Iguaçu & $925 \mathrm{~b}$ & $210 \mathrm{~b}$ & $0.77 \mathrm{~b}$ \\
\hline FPS Nitron & $1350 \mathrm{~b}$ & $325 \mathrm{~b}$ & $1.12 \mathrm{~b}$ \\
\hline Marfim & $1117 \mathrm{~b}$ & $218 \mathrm{~b}$ & $0.93 \mathrm{~b}$ \\
\hline $\mathrm{CV}(\%)$ & 24.5 & 31.7 & 26.2 \\
\hline \multicolumn{4}{|c|}{ Year 2016 (evaluated at 83 days after inoculation) } \\
\hline Tomato & $1910 \mathrm{a}$ & $376 \mathrm{a}$ & $1.59 \mathrm{a}$ \\
\hline F. Cristalina & $890 \mathrm{~b}$ & $67 \mathrm{~b}$ & $0.74 \mathrm{~b}$ \\
\hline IPR 85 & 1628 a & $156 \mathrm{~b}$ & $1.36 \mathrm{a}$ \\
\hline IPR 144 & $872 \mathrm{~b}$ & $89 \mathrm{~b}$ & $0.73 \mathrm{~b}$ \\
\hline IPR Catuara Tm & $1190 \mathrm{~b}$ & $102 \mathrm{~b}$ & $0.99 \mathrm{~b}$ \\
\hline BRS Tangará & $712 \mathrm{~b}$ & $69 \mathrm{~b}$ & $0.59 \mathrm{~b}$ \\
\hline BRS Gaivota & $1990 \mathrm{a}$ & $113 \mathrm{~b}$ & $1.66 \mathrm{a}$ \\
\hline Quartzo & $960 \mathrm{~b}$ & $61 \mathrm{~b}$ & $0.80 \mathrm{~b}$ \\
\hline BRS Sabiá & $733 \mathrm{~b}$ & $52 \mathrm{~b}$ & $0.61 \mathrm{~b}$ \\
\hline BRS Gralha Azul & $1304 \mathrm{~b}$ & $83 \mathrm{~b}$ & $1.09 \mathrm{~b}$ \\
\hline T. Bio Iguaçu & $876 \mathrm{~b}$ & $57 \mathrm{~b}$ & $0.73 \mathrm{~b}$ \\
\hline FPS Nitron & $342 \mathrm{~b}$ & $23 \mathrm{~b}$ & $0.28 \mathrm{~b}$ \\
\hline Marfim & $764 \mathrm{~b}$ & $53 \mathrm{~b}$ & $0.64 \mathrm{~b}$ \\
\hline $\mathrm{CV}(\%)$ & 28.72 & 36.48 & 24.64 \\
\hline
\end{tabular}

Means followed by the same letters within a column do not differ statistically according to Scott-Knott test at $5 \%$. Original means were transformed by $\sqrt{ }(x+0.5)$ for statistical analysis. $C V=$ coefficient of variation $(\%)$.

\section{DISCUSSION}

For analysis of the cultivars responses to $P$. brachyurus, 83 DAI was the best experimental condition to identify differences among treatments. Probably the longest period for nematode multiplication favored the observation of susceptible cultivars, since little difference in responses was verified in the temperatures between experimental periods. Such results corroborate those of Silveira (2012), who observed better detection of $P$. brachyurus reproduction at more than 60 DAI, in an initial population of 1,200 nematodes in soybean. In addition, the author also observed that the ideal period to identify maximum nematode reproduction was 80 DAI.

Despite variations, the studied cultivars were generally susceptible to $P$. brachyurus, except the cultivars F. Cristalina and IPR 85. Even through there 
are a few studies about wheat reaction to this nematode, our results corroborate the findings of Chiamolera et al. (2012), who observed that the wheat cultivar CD 117 was one of the winter crops most susceptible to $P$. brachyurus in both field and greenhouse experiments.

However, our results differ from those obtained at North Carolina, where the population of $P$. brachyurus was decreased with winter wheat cultivation, when compared to fallow areas (KOENNING et al., 1985). In this case, factors such as soil type, wheat genotype and mainly climate have probably influenced the results. It is noteworthy that in addition to $P$. brachyurus, wheat hosts other species of root-lesion nematodes such as $P$. penetrans Cobb, $P$. neglectus and $P$. thornei (SMILEY et al., 2005; MOKRINI et al., 2016). Wheat cultivars resistant to $P$. thornei did not inhibit attraction and penetration of nematodes but restricted migration and reduced reproduction by inhibiting the maturation of second stage juveniles (J2) to third stage juveniles (J3) (LINSELL et al., 2014).

Greater multiplication of $M$. javanica was observed at 60 DAI. Probably this increased reproduction is related to the season in which experiment was performed. High temperatures on summer have probably facilitated nematode reproduction (KALOSHIAN et al., 1989) in the first experiment.

Our results for $M$. javanica agree with observations made in other works. Sharma (1981) found that 21 wheat varieties were susceptible to $M$. javanica by analyzing galls indices and egg masses of nematodes. In addition, the author verified the pathogenicity of $M$. javanica by comparing the cultivars Confiança $(\mathrm{RF}=11.53)$ and Alondra $4546(\mathrm{RF}=1.04)$. Both cultivars presented reduced root system and galls, followed by symptoms of dwarfism and yellowing (SHARMA, 1982). Howerver, Brida (2012) observed that cultivars CD-118, CD-104, CD-108, CD-150, BRS-220, BRS-Pardela and BRS-Tangará were resistant or immune to $M$. javanica and $M$. incognita (Kofoid and White) Chitwood. Costa and Ferraz (1990) verified that wheat did not have antagonistic effect to $M$. javanica when compared to pigeon pea (Cajanus cajan).

In our study, the cultivar BRS Tangará presented RF values of 0.93 and 0.59 in analyses at 60 and 83 DAI, whereas Brida (2012) classified the same cultivar as immune in two different experimental periods, both at $60 \mathrm{DAI}$. Substrate, experimental unit, cultural dealings are conditions that can influence in the nematode reproduction, among other factors. However, variations in response of the cultivar BRS Tangará could be also due to the initial population of nematode used in the study. Kaloshian et al. (1989) observed that different isolates of the same $M$. incognita race presented variable reproduction rate in wheat cultivars. The authors suggest that aggressive populations of a certain species of Meloidogyne can also reproduce in cultivars considered resistant. However, even with variations, BRS Tangará could still be used in areas infested with $M$. javanica since it would permit lower levels of reproduction than the other genetic materials evaluated in this study.

It is worth mentioning that some cultivars presented RF close to 1 under greenhouse conditions, where root systems developed in pots with a limited growth. Evidently this condition does not represent the reality of nematode reproduction and population maintenance under field conditions, where density of plants is higher as well as the volume of the root systems. In addition, a complete wheat cycle lasts approximately 120 days in the field.

The studied cultivars presented different responses to both nematodes in terms of multiplication. Therefore, in infested areas, the choice of a cultivar would influence the soil nematode population in terms of decrease, increase or maintenance.

Thus, this present study were possible to observe that wheat cultivars IPR Catuara TM, IPR 144, BRS Gralha Azul, BRS Sabiá, BRS Gaivota, BRS Tangará, Marfim, FPS Nitron, T.Bio Iguaçu and Quartzo were susceptible to $P$. brachyurus. Only cultivars F. Cristalina and IPR 85 were resistant to $P$. brachyurus under an initial population of 1,200 specimens. Cultivars BRS Gaivota, IPR 85, BRS Sabiá, F. Cristalina, IPR 144, IPR Catuara Tm, Quartzo, FPS Nitron and BRS Gralha Azul were susceptible to $M$. javanica in at least one experiment.

\section{REFERENCES}

BONETI, J.I.S., FERRAZ, S. Modificação do método de Hussey e Barker para extração de ovos de Meloidogyne exigua de raízes de cafeeiro. Fitopatologia Brasileira, v. 6, p. 553, 1981.

BRIDA, A.L. Reação da aveia branca, feijão, sorgo e trigo a Meloidogyne incognita, M. javanica e M. enterolobii. 2012. Dissertação (Mestrado em Agronomia) Universidade Estadual Paulista, Botucatu, São Paulo, 2012. 
CHIAMOLERA, F.M., DIAS-ARIEIRA, C.R., SOUTO, E.R., BIELA, F., CUNHA, T.P.L., SANTANA, S.M., PUERARI, H.H. Suscetibilidade de culturas de inverno a Pratylenchus brachyurus e atividade sobre a população do nematoide na cultura do milho. Nematropica, v. 42, p. 267-275, 2012.

COLEEN, W.A., D'HERDE, C.J. A method for the quantitative extraction of nematodes from plant tissue. Ghent: State Agriculture Research Center, p. 77, 1972.

CONAB - COMPANHIA NACIONAL DE ABASTECIMENTO. Acompanhamento da safra Brasileiro-monitoramento agrícola (Safra 2015/16), v. 3, p. 1-149, 2015.

COSTA, D.C., FERRAZ, S. Avaliação do efeito antagônico de algumas espécies de plantas, principalmente de inverno a Meloidogyne javanica. Nematologia Brasileira, v. 14, p. 61-70, 1990.

DIAS, W.P., GARCIA, A., SILVA, J.F.V., CARNEIRO, G.E.S. Nematoides em soja: Identificação e Controle. Londrina, Embrapa Soja, p.8, 2010.

FERREIRA, D.F. SISVAR: um programa para análises e ensino de estatística. Revista Symposium, v. 6, p. 3641, 2008.

KALOSHIAN, I., ROBERTS, P.A., THOMASON, I. Resistance to Meloidogyne spp. in allohexaploid wheat derived from Triticum turgidum and Aegilops squarrosa. Journal of Nematology, v. 21, n. 1, p. 42-47, 1989.

KOENNING, S.R., SCHMITT, D.P., BARKER, K.R. Influence of selected cultural practices on winter survival of Pratylenchus brachyurus and subsequent effects on soybean yield. Journal of Nematology, v. 17, p. 464469, 1985.

LINSELL, K.J., RILEY, I.T., DAVIES, K.A., OLDACH, K.H. 2014. Characterization of resistance to Pratylenchus thornei (nematoda) in wheat (Triticum aestivum): attraction, penetration, motility, and reproduction. Phytopathology, v. 104, n. 2, p. 174-187, 2014.
MOKRINI, F., WAEYENBERGE, L., VIAENE, N., ANDALOUSSI, F.A., MOENS, M. Diversity of rootlesion nematodes (Pratylenchus spp.) associated with wheat (Triticum aestivum and T. durum) in Morocco. Nematology, v. 18 p. 781-801, 2016.

NYCZEPIR, A.P., INSERRA, R.N., O'BANNON, J.H., SANTO, G.S. Influence of Meloidogyne chitwoodi and $M$. hapla on Wheat Growth. Journal of Nematology, v. 16, p. 162-165, 1984.

OOSTENBRINK, M. Major characteristics of the relation between nematodes and plants. Mendeling. Landbouwh. Sch., v. 66 p. 1-46, 1996.

SANTOS, T.F.S. Metodologia de avaliação a Pratylenchus brachyurus e reação de genótipos de soja aos nematoides das galhas e das lesões. 2012. Dissertação (Mestrado em Engenharia Agrícola) - Universidade Federal do Mato Grosso, Rondonópolis, 2012.

SHARMA, R.D. Patogenicidade do nematoide Meloidogyne javanica ao trigo (Triticum aestivum L.). In: Reunião Brasileira de Nematologia. Sociedade Brasileira de Nematologia, 5, 1982, Fortaleza, p. 109118.

SHARMA, R.D. Resistência de cultivares de trigo (Triticum aestivum L.) ao nematoide Meloidogyne javanica (Treub, 1885) Chitwood, 1949. Sociedade Brasileira de Nematologia, v. 5, p. 120-127, 1981.

SMILEY, R.W., WHITTAKER, R.G., GOURLIE, J.A., EASLEY, S.A. Suppression of wheat growth and yield by Pratylenchus neglectus in the Pacific Northwest. Plant Disease, v. 89 p. 958-968, 2005.

SMILEY, R.W., GOURLIE, J.A., YAN, G., RHINHART, K.E.L. Resistance and tolerance of landrace wheat in fields infested with Pratylenchus neglectus and P. thornei. Plant Disease, v. 98, p. 797-805, 2014.

WILLIAMS, K., TAYLOR, S., BOGACKI, P., PALLOTA, M., BARIANA, H., WALLWORK, H. Mapping of the root lesion nematoide (Pratylenchus neglectus) resistance gene Rlnn1 in wheat. Theor. Appl. Genet, v. 104, p. 874-879, 2002. 